\title{
EVALUATION OF PRODUCTIVE PERFORMANCE OF BROILER BREEDERS AT SOME COMMERCIAL FARMS DURING REARING PERIOD
}

\author{
M. E. Soltan, S. A. Farrag and M. F. Deraz \\ Poultry and Fish production Department, Faculty of Agriculture, Menoufia University, \\ Egypt. \\ Received: Feb. 17, 2020 \\ Accepted: Feb. 26, 2020
}

\begin{abstract}
Aiming to evaluate the productive performance of some commonly found in Egypt broiler breeders' strains (i.e. Arbor Acres, Hubbard, Indian River, Cobb 500 and Ross 308), the current study was carried out at some commercial farms in three different governorates (North Sinai, Ismailia and Fayoum) during the period from 2015 to 2019. Records of 99455 broiler parent females (23440, 18800, 20623, 12480 and 24112 females) from Arbor Acres, Hubbard, Indian River, Cobb 500 and Ross 308 broiler breeders, respectively, were collected and used in the present study. All studied strains reared under close house conditions according to their management guides from breeding companies. Results showed that, body weight at receiving time for different strains ranged between $32.56 \mathrm{~g}$ (Hubbard) to $42.42 \mathrm{~g}$ (Arbor Acres). Arbor acers pullets reached $2092.5 \mathrm{~g}$ body weight at sixteenth week of age, while the lightest weight at this age detected for Indian River pullets (1683.0 g). After photo-stimulation, reaching sexual maturity, Hubbard pullets recorded the heavier body weight as $3032.25 \mathrm{~g}$ comparing with 2954.48, 2919.67, 2861.75 and $2822.5 \mathrm{~g}$ for Ross, Cobb, Indian River and Arbor Acers broiler breeder pullets, respectively. Statistical analysis revealed highly significant $(P \leq 0.01)$ differences between strains at receiving time and 24 weeks of age. Results revealed that, daily and cumulative feed consumption differed significantly $(P \leq 0.01)$ at first week of age among studied strains, however, the differences in daily and cumulative feed consumption were not significant at 24 weeks of age. Current results could help to predict and evaluate the performance of breeders during production cycle.
\end{abstract}

Key words: broiler breeders, rearing period, commercial.

\section{INTRODUCTION}

The management process of modern broiler breeders became very complicated and challenge due to the continuous genetic improvements for individual strain. These improvements for the most important economic traits (i.e. growth rate, feed conversion and meat yield) increased the challenge facing breeder managers, and may be have a negative effect on egg production and reproductive performance of broiler parents.

Basically, to achieve good egg production and persistency, pullets should be ideally prepared during rearing period, and producers should work for high uniformity, body confirmation and body weight profile by feed management (Yıldırım and Yalçınalp, 2018). Breeders that not reached the target body weight needed for sexual maturity will not commenced egg production (van der Klein et al., 2018). There is a big challenge to control body weight in the period between starting photostimulation and the production peak (Yıldırım and Yalçınalp, 2018). Heavier hens start to lay eggs latter than standard weighed hens, this delay leads to reduction of peak production, and mortality due to heavy weight may occur.

Productive performance of parent stocks influenced by many non-genetic factors. One of these factors is body 
weight during production period (it is mainly depending on body weight at rearing period), which considered one of the key factors that affect breeder's performance. When growth rate is excessive, productivity declines due to many ovulations, and conversely, if feed restriction is too severe, egg production will be decreased due to the delay of ovulation and the target will not acquire (Álvarez and Hocking, 2007). So, feed restriction is uninterrupted during the whole life period of commercial broiler breeders' stocks, specially the rearing period (in most cases, during the first two weeks of age the breeder chicks have ad libitum access to their food).Breeding companies utilize many of genetically varied stocks to improve the most economically important traits (i.e. body weight, egg production, egg weight and chick quality) in their breeding plans.

In Egypt, mainly due to the growth of population and gross domestic product, there is a growing demand by consumers for low-price animal protein, such needs give an opportunity to broiler chicken meat production to increase. On the other hand, Egyptian poultry association estimated 2017's poultry meat consumption in Egypt by $43 \%$ of total consumed animal protein in Egypt (FAO, 2017).Commercially, the most crosses found in Egypt are Ross, Cobb, Arbor Acres, Indian River and Hubbard from the major breeding companies. Performance of broiler breeders differed from one country to another (Yıldırım and Yalçınalp, 2018). Egypt, as one of developing countries, may have lower performance of broiler breeder flocks due to many factors including: management conditions, low feed quality, diseases and the management staff.

\section{MATERIALS AND METHODS}

Aiming to evaluate the performance of some broiler breeders' genotypes during rearing period, current study was carried out at some commercial farms in three different governorates in Egypt (North Sinai, Ismailia and Fayoum) during the period from 2015to 2019. Data of the most five commonly found in Egypt broiler breeders' strains have been studied (i.e. Arbor Acres, Hubbard, Indian River, Cobb 500 and Ross 308).

\section{Breeding system and management:}

All studied farms were closed houses (with controlled environment) and the system applied for rearing period was floor breeding system on deep litter (wood shavings). Broiler breeder chicks received and maintained at $32.2-33^{\circ} \mathrm{C}$ for the first week, then a gradual decrease was practiced by approximately $2.8^{\circ} \mathrm{C} /$ week till reaching the standard temperature $\left(21^{\circ} \mathrm{C}\right)$ at 5 weeks of age.

\section{Experimental broiler breeder strains and numbers:}

Data presented in Table (1) showed the location, house area, number of houses and number of birds for all studied farms and strains. Records of total number of 99455 broiler parent females were collected and used in the present study.

\section{The studied traits:}

\section{Body weight at different ages $\left(B W_{x}\right)$ :}

Body weight at the day of receiving birds $\left(B W_{R}\right)$ and at $6,10,16$, and 24weeks of age $\left(\mathrm{BW}_{6}, \mathrm{BW}_{10}, \mathrm{BW}_{16}\right.$, and $\left.\mathrm{BW}_{24}\right)$ have been recorded for current study. These weights were taken at morning before feeding, randomly and individually by using number of birds representing about $3 \%$ of the total number of birds in the house (every farm included 3 or 4 houses). The average values of body weight of the sampled birds were used in data analysis. 
Table (1): Number of birds distributed on farms, strains, houses number, house space and location.

\begin{tabular}{lclcccc}
\hline Location & Farm & Strain & $\begin{array}{c}\text { N. of } \\
\text { Houses }\end{array}$ & $\begin{array}{c}\text { House space } \\
\left(\mathrm{m}^{2}\right)\end{array}$ & \multicolumn{2}{c}{ Number of birds } \\
\hline Ismailia & 1 & Arbor Acres & 4 & 1200 & 23440 & 3154 \\
& 2 & Hubbard & 4 & 920 & 18800 & 2560 \\
North Sinai & 3 & Indian River & 4 & 960 & 20623 & 3075 \\
& 4 & Cobb 500 & 3 & 840 & 12480 & 2000 \\
Fayoum & 5 & Ross 308 & 4 & 1200 & 24112 & 3980 \\
Total & 5 & ---- & 19 & $19640 \mathrm{~m}^{2}$ & 99455 & 14769 \\
\hline
\end{tabular}

Daily and cumulative feed consumption (g/bird) on weekly basis:

Daily $\left(\mathrm{FC}_{\mathrm{x}}\right)$ and cumulative (CFC $\mathrm{C}_{\mathrm{x}}$ ) feed consumption by bird during rearing period were recorded on weekly basis (g/bird). Birds freely accessed water, and received a typical restricted amount of feed according to management guides to control their growth and maintain the target weights as possible.

Daily feed consumption (g/bird)

$=\left(\frac{\text { Total feed consumed }(\mathrm{g})}{\text { Total number of birds }}\right) /$ number of days

Cumulative feed consumption ( $g$ )

$=($ Daily feed consumption $(g) \times 7)$

+ Previous cumulative feed consumption $(g)$

\section{Stocking density on weekly basis (StD):}

Actual stocking densities have been recorded on weekly basis for all houses in the investigated farms (birds $/ \mathrm{m}^{2}$ ). Due to sexing errors and culling processes and mortality, actual stocking densities changes from farm to farm and from time (age) to time (age).
Stocking density (bird $/ \mathrm{m}^{2}$ )

$$
=\frac{\text { Total number of birds }}{\text { Total avilable area }\left(\mathrm{m}^{2}\right)}
$$

\section{Statistical analysis: -}

Data were computerized and variance analyzed according the following model (one-way) by software program SPSSIBM v. 21.0 (2012) using General Linear Models (GLM). Significant differences among means were detected by Duncan test procedure implemented in the SPSS software (2012).

Model:

Where:

$$
Y_{i j}=\mu+S_{i}+e_{i j}
$$

$Y_{i j}=$ the value of the trait (observation)

$\mu=$ the general mean of the trait

$S_{i}=$ the fixed effect of $i^{\text {th }}$ strain on studied trait ( $i=$ Arbor Acres, Hubbard, Indian River, Cobb and Ross).

$e_{i j}=$ residual effect .

\section{RESULTS AND DISCUSSION Effect of strains on body weight at different ages:}

Data presented in Table (2) showed body weight at different ages for 
investigated commercial breeder strains. Body weight at receiving time (first day in the farm) for different strains ranged between $32.56 \mathrm{~g}$ (Hubbard) to $42.42 \mathrm{~g}$ (Arbor Acres). Many researchers recorded higher values (except for Arbor Acres chicks) of body weight at receiving day of broiler breeder chicks that detected in recent study, they recorded 40.0 and $44.42 \mathrm{~g}$ for Arbor Acres; 40.7 and $40.33 \mathrm{~g}$ for Hubbard; and $42.0 \mathrm{~g}$ for Indian River chicks (Hameed et al., 2005 and Hameed et al., 2012). It is known that chick weight significantly correlated to egg weight that is hatching from, additionally, differences between the sources, environments and incubation management condition also may affect chick weight. So, the slight differentiation in body weight at receiving time could be attributed to above mentioned factors.

At six weeks of age Ross breeders' chicks showed the highest body weight among all studied strains (1142.23 g) while the lowest $(741.67 \mathrm{~g})$ recorded for Indian River breeders' chick. Reaching the tenth week of age the same trend as in the sixth week have been observed and the highest body weight assigned to Ross breeders' chicks 1357 g comparing with $1278.75 \mathrm{~g}$ for Arbor acers, $1254.33 \mathrm{~g}$ for Cobb, $1230.25 \mathrm{~g}$ for Hubbard and the lowest weight recorded by Indian River breeders' chicks as $1093.75 \mathrm{~g}$. Reviewing breeder performance targets for all strains under investigation, we found that Cobb 500 breeders were the heaviest at 6 and 10 weeks of age, however, Arbor Acres breeders were the lightest birds. Arbor acers pullets reached $2092.5 \mathrm{~g}$ body weight at sixteenth week of age, while the lightest weight at this age detected for Indian River chicks (1683.0 g). After photo-stimulation and reaching sexual maturity, Hubbard pullets recorded the heavier body weight as 3032.25 g comparing with 2954.48,
2919.67, 2861.75 and $2822.5 \mathrm{~g}$ for Ross, Cobb, Indian River and Arbor Acers broiler breeder pullets, respectively.

Statistical analysis revealed highly significant $(P \leq 0.01)$ differences between strains at receiving time and at $6,10,16$ and 24 weeks of age as presented in Table (2). Although, observed values of body weight at 6,10 and 16 weeks of age were higher that the corresponding values targeted by breeding companies (management guides for studies strains), breederssucceeded in the $24^{\text {th }}$ week of age to keep the body weight of pullets around the target, slightly higher. The same trend was reported by Djermanovic and Mitrovic (2018). Lower values of $\mathrm{BW}_{24}$ that the detected means in the recent research have been reported previously for Hubbard (Zuidhof et al., 2007), Cobb 500 (Renema et al., 2001; Djermanovic and Mitrovic, 2018) and Ross 308 (Djermanovic and Mitrovic, 2018) broiler breeders' pullets. Regarding statistical differences observed in all studied ages in current study, Djermanovic and Mitrovic (2018) reported that genotype didn't affected body weight of laying hen significantly. This could be attributed to the different management conditions and strains under investigation by different researchers.

Effect of strains on daily and cumulative feed consumption of broiler breeders:

Due to the high genetic potential for broiler breeder genotypes, the pullets must be subjected to feed restriction to control their body weight, and successfully entered laying phase. It has been reported that commercial broiler breeders should be subjected to restricted control of the amount of feed supplied to them (Tolkamp et al., 2005). 


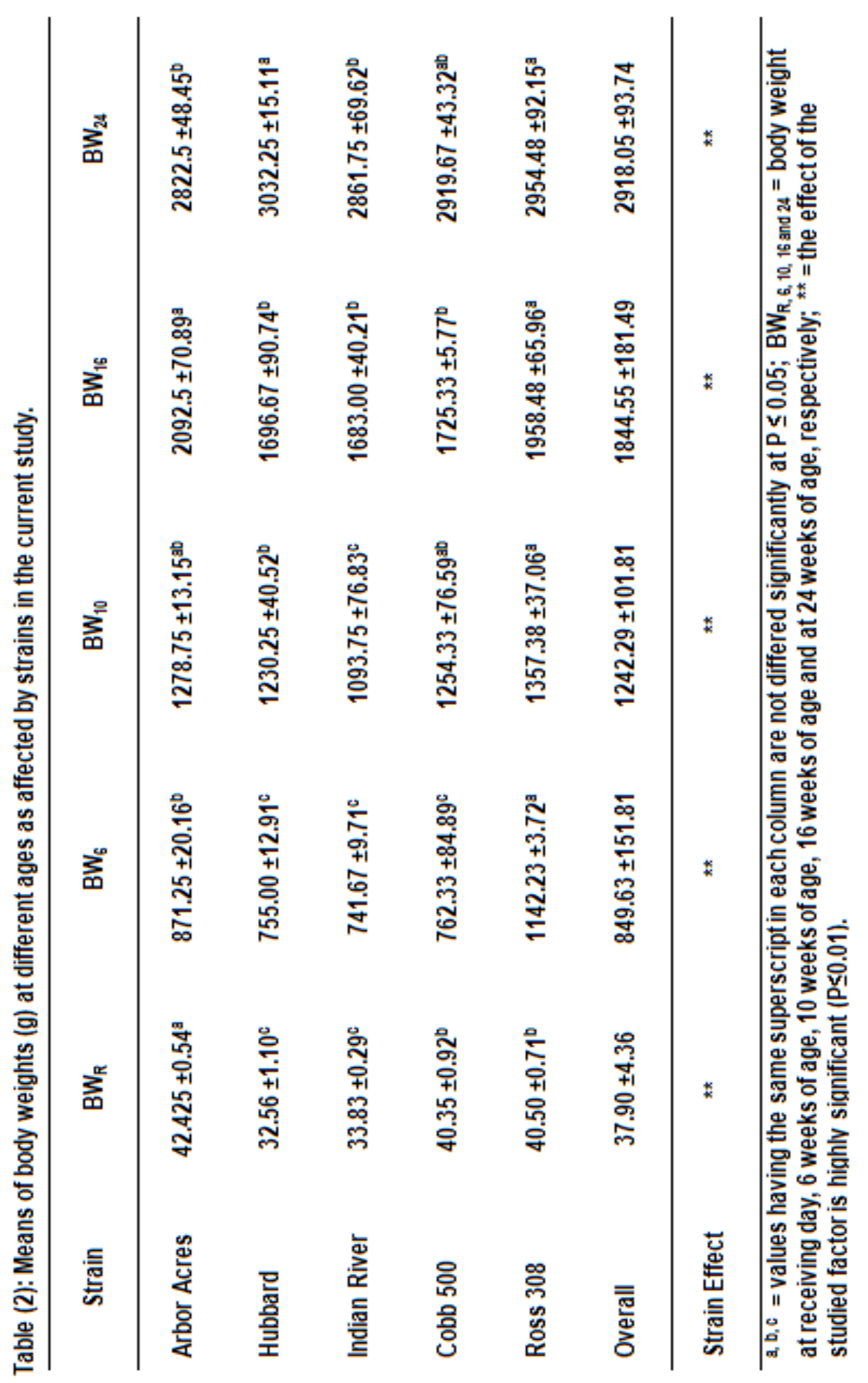


Means of daily feed consumption for studied strains presented in Table (3). Average values of daily feed consumption for all strains were 32.78, $43.13,54.11,75.32$ and $123.58 \mathrm{~g}$ at one day, $6,10,16$ and 24 weeks of age, respectively. Results revealed that, daily feed consumption differed significantly $(P \leq 0.01)$ until six weeks of age among studied strains, however, the differences in daily feed consumption were not significant at 10, 16 and 24 weeks of age (Table, 3). Unfortunately, we did not find any paper in available resources dealing with daily feed consumption of current studied broiler breeder strains, however, the amount of daily feed practiced and fully agreed with recommended daily intake by breeding companies, except at $24^{\text {th }}$ week of age, daily feed intake overall average (123.58 $\mathrm{g} /$ day) for studied strains was lower than the recommended by its breeding companies with a range of 129 $131 \mathrm{~g} /$ day/bird). This is very known practice that may be applied to control the higher body weights observed in previous ages of the bird's life, and regressed again to the optimal body weight that recommended by breeding companies.

Data in Table (4) showed the cumulative feed consumption for all broiler breeder strains under investigation. Significant differences between strains were detected by statistical analysis until 16 weeks of age, however, there were no significant differences between studied strains in cumulative feed consumption at 24 weeks of age. The grand mean values of cumulative feed consumption during the rearing period across all strains investigated were 187.73, 1227.63, 2334.68, 5084.95 and $10749.79 \mathrm{~g}$ after 1 , $6,10,16$ and 24 weeks of age, respectively. Higher values of cumulated feed intake during rearing period (i.e. 0 24 weeks of age) have been recorded by Hameed et al., 2012 (13.85 kg - Arbor Acres; $14.12 \mathrm{~kg}$ - Hubbard) than those detected (range of $10.33-11.32 \mathrm{~kg}$ ) in our research. Results are fully agreed with those found by England et al. (2014) and van Emous et al. (2015) for Ross 308 breeder pullets. van der Klein et al., 2018 found that during the rearing phase, cumulative feed intake was lower for hens on the standard BW treatment compared to hens on the high $\mathrm{BW}$ treatment.

\section{Actual stocking densities for different studied strains:}

Actual stocking densities at different ages for studied strains have been recorded in Table (5). For the first, sixth, tenth, sixteenth and twenty-fourth weeks of age, stocking densities averaged in general 27.58, 14.00, 5.62, 5.64 and 5.38 $\mathrm{bird} / \mathrm{m}^{2}$. Stocking density differed significantly between strains (Table, 5 ). It was applied also according to recommendations of management guides of studied strains. Since, wrong stocking density could be one of the factors leading to lower performance of egg production (Hellwig and Ranson, 2005), because of the competence for restricted amount of feed - if stocking density settled as higher number of birds $/ \mathrm{m}^{2}-$ or over feeding when density of birds kept lower, in addition to hygienic problems. Stocking density should be continually monitored and adjusted.

Results obtained in the current study could help evaluating and assessing performance of investigated broiler breeder strains, since the production performance mainly affected by the performance of breeder hens during the rearing period as discussed above. 


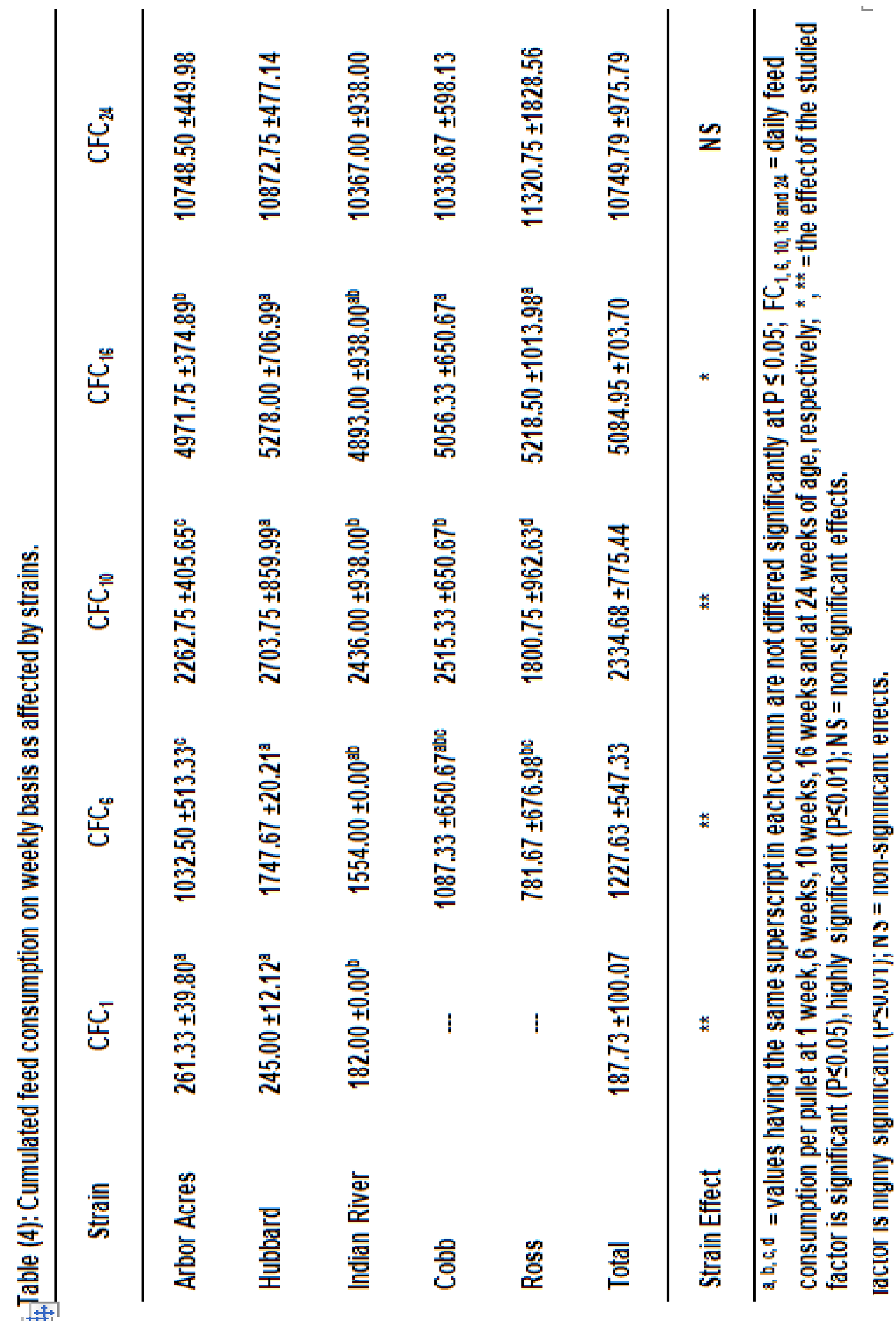


M. E. Soltan, et al.,

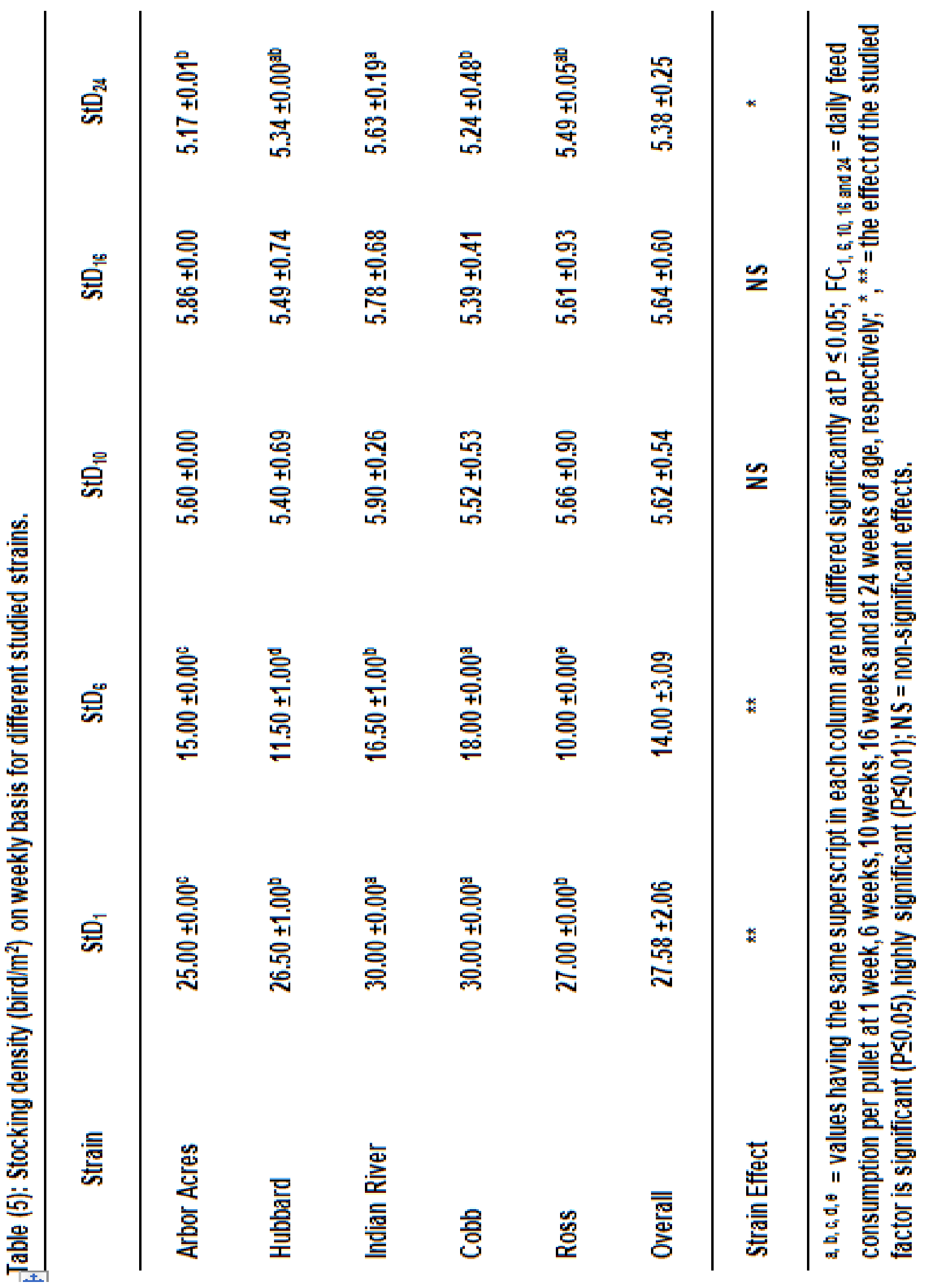




\section{REFERENCES}

Álvarez, R. and P. M. Hocking (2007). Stochastic Model of Egg Production in Broiler Breeders. Poultry Science 86:1445-1452.

Djermanovic, V. and S. Mitrovic (2018). Phenotype correlation between production traits and body weight of heavy broiler breeder hens. Agriculture \& Forestry, Vol. 64 Issue 2: 113-119, 2018, Podgorica.

England, J.A., J.R. Moyle, D.E. Yoho, R.K. Bramwell, R.D. Ekmay, R. Kriseldi and C.N. Coon (2014). Effect of rearing program, body conformation and protein level of breeder feed on broiler breeder hen reproductive performance. International Journal of Poultry Science 13 (1 2): 670-679.

FAO: Yevgen Shatokhin, Mohammed EI Gammal and Dmitry Prikhodko (2017). Arab Republic of Egypt: Broiler poultry industry: investment challenges and opportunities (Draft for discussion). FAO, Rome, Italy.

Hameed Tahir, Naeem Tariq, Mohammad Azam Kakar, Khuda-ai-dad Tareen and Sohail Hassan Khan (2005). A Comparative Economic Analysis of Productivity and Hatchability Traits in Parent Strains of Commercial Chicken in Pakistan. J. App. Em. Sc.: I (2) 7-12.

Hameed Tahir, Masroor Ahmad Bajwa, Ferhat Abbas, Abdul Waheed Sahota, Mohammad Masood Tariq, Sohail Hassan Khan and Farhat Abbas Bokhari (2012). Effect of Housing System on Production Performances of Different Broiler Breeder Strains. Pakistan J. Zool., vol. 44(6), pp. 16831687.

Hellwig, M. and J. Ranson (2005). Troubleshooting egg production problems. Hubbard breeders
Technical Services, Bulletin

Technical; www.hubbardbreeders.com

IBM Corp. Released (2012). IBM SPSS Statistics for Windows, Version 21.0. Armonk, NY: IBM Corp.

Renema, R. A., F. E. Robinson and P. R. Goerzen (2001). Effects of altering growth curve and age at photostimulation in female broiler breeders. $1 . \quad$ Reproductive development. Can. J. Anim. Sci. 81:467-476.

Tolkamp, B. J., V. Sandilands and I. Kyriazakis (2005). Effects of Qualitative Feed Restriction During Rearing on the Performance of Broiler Breeders During Rearing and Lay. Poultry Science 84:1286-1293.

van der Klein, S. A. S., G. Y. Bédécarrats and M. J. Zuidhof (2018). The effect of rearing photoperiod on broiler breeder reproductive performance depended on body weight. Poultry Science 97:3286-3294.

van Emous, R. A., R. P. Kwakkel, M. M. van Krimpen and W. H. Hendriks (2015). Effects of dietary protein levels during rearing and dietary energy levels during lay on body composition and reproduction in broiler breeder females. Poultry Science 94:10301042.

Yıldırım, Z. and M. Yalçınalp (2018). Preparing Broiler Breeder Females for Optimum Production. International Poultry Science Congress of WPSA Turkish Branch'2018: 56 - 61.

Zuidhof, M. J., R. A. Renema and F. E. Robinson (2007). Reproductive Efficiency and Metabolism of Female Broiler Breeders as Affected by Genotype, Feed Allocation, and Age at Photostimulation. 3. Reproductive Efficiency. Poultry Science 86:22782286. 
M. E. Soltan, et al.,

تقييم الأداء الإنتاجى لأمهات هجن إنتاج اللحم في بعض المزارع التجارية خلال فترة الرعاية

\author{
محمد السيد سلطان، سامى عبد الحى فراج، محمد فوزى دراز
}

قسم إنتاج الدواجن والأسماك - كلية الززاعة - جامعة المنوفية

الملخص العربى

أجريت الاراسة بهدف تقييم الأداء الإنتاجى لبعض أمهات هجن إنتاج اللحم الثائع انتثارها في مصر (أريور إيكرز،

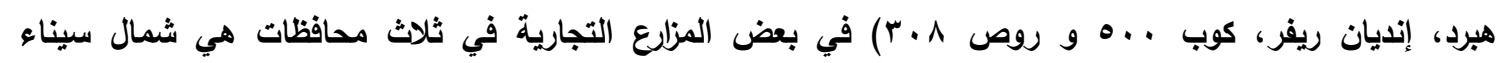

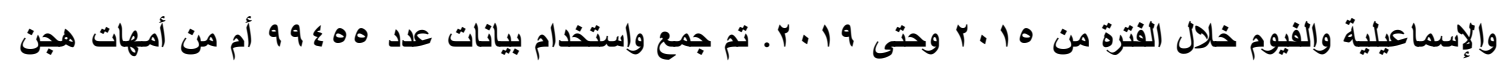

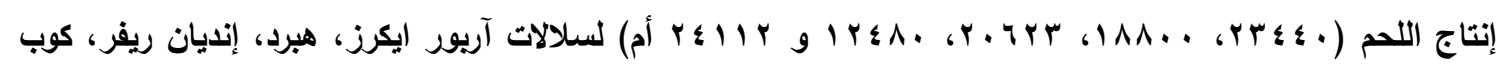

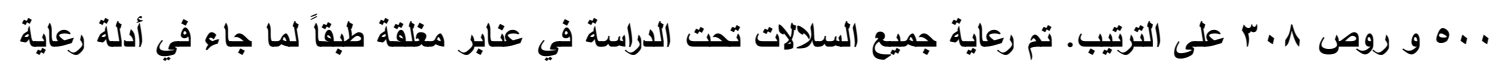

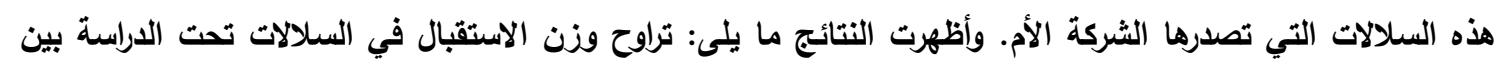

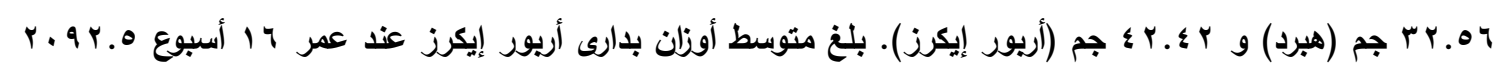

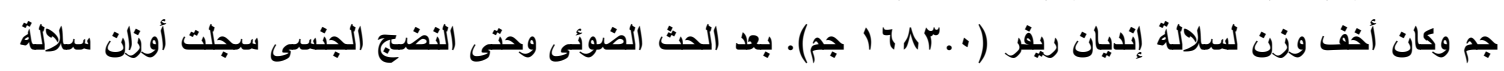

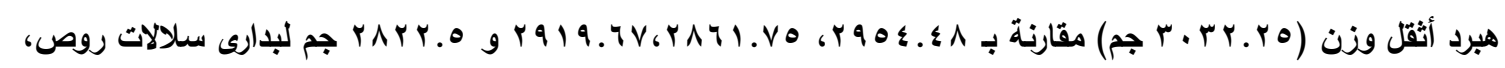

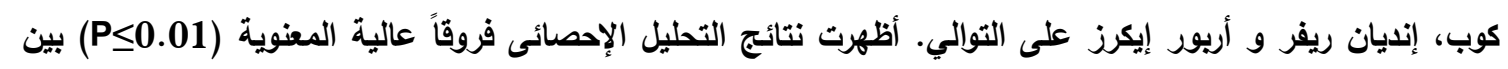

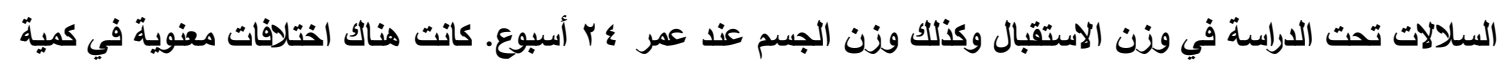

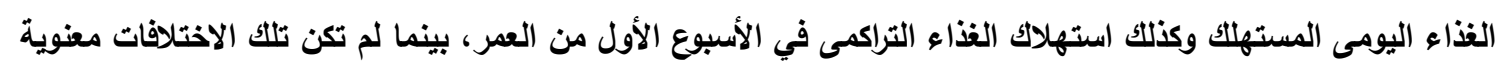

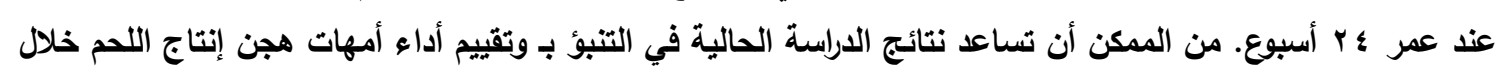
فترة الإنتاج. 
Evaluation of productive performance of broiler breeders at some .................. 